\title{
Nitrogen metabolism of four raw meat diets in domestic cats
}

\author{
Katherine R. Kerr ${ }^{1}$, Alison N. Beloshapka ${ }^{2}$, Cheryl L. Morris ${ }^{3}$ and Kelly S. Swanson ${ }^{1,2 *}$ \\ ${ }^{1}$ Division of Nutritional Sciences, University of Illinois, Urbana, IL 61801, USA \\ ${ }^{2} 132$ Animal Sciences Laboratory, Department of Animal Sciences, 1207 West Gregory Drive, Urbana, IL 61801, USA \\ ${ }^{3}$ Omaha's Henry Doorly Zoo, Omaha, NE 68107, USA \\ (Received 15 October 2010 - Revised 27 November 2010 - Accepted 28 January 2011)
}

\begin{abstract}
Little nutritional information has been collected from domestic cats fed raw meat diets. The objective of the present study was to evaluate differences in $\mathrm{N}$ metabolism of domestic cats fed raw beef-based diet ( $66 \%$ crude protein (CP) and $20 \%$ fat), bison-based diet ( $49 \% \mathrm{CP}$ and $39 \%$ fat), elk-based diet (79\% CP and 6\% fat) and horse-based diet (60\% CP and $26 \%$ fat). A total of eight intact adult female cats were fed to maintain body weight in a cross-over design. Daily food intake, faecal and urinary outputs, and $\mathrm{N}$ metabolism were measured. Dietary $\mathrm{N}$ was highly digestible (96.8 (SEM 0.7)) for all treatments. Urinary $\mathrm{N}$ accounted for a majority of total $\mathrm{N}$ excretion, and differences in total $\mathrm{N}$ excretion reflect differences in urinary $\mathrm{N}$. Differences in $\mathrm{N}$ intake and $\mathrm{N}$ absorption were due to differences in CP levels among diets. $\mathrm{N}$ retention was similar to values reported in the literature for domestic cats fed purified and traditional extruded diets. Despite differences in protein concentrations and $\mathrm{N}$ intake, all raw meats tested maintained $\mathrm{N}$ metabolism.
\end{abstract}

Key words: Cats: Nitrogen metabolism: Raw diets

There is an increasing trend for the feeding of unconventional diets, including raw meat-based diets, to companion animals ${ }^{(1,2)}$. Raw diets have been used for Sled dogs, racing Greyhounds $^{(3)}$ and captive exotic cats ${ }^{(2)}$; however, the nutritional adequacy of raw meat diets for domestic cats has not been adequately studied. Raw beef- and horse meat-based diets have been shown to be highly digestible ${ }^{(4-8)}$ and maintain body weight $(\mathrm{BW})^{(6,7)}$; however, studies have focused on beef- and horse meat-based diets with little attention to alternative meat sources. Meat sources may have tremendous variation in composition depending on a multitude of factors including animal species and feeding practices. To our knowledge, studies to determine the effects of varying raw meat sources on $\mathrm{N}$ metabolism in domestic cats have not been performed. The objective of the present study was to compare $\mathrm{N}$ metabolism of domestic cats fed four raw meat-based diets. We hypothesised that all diets would result in a similar $\mathrm{N}$ retention, and therefore be suitable protein sources for adult cats.

\section{Materials and methods}

\section{Experimental design and animals}

A total of eight intact adult female domestic shorthair cats (Felis catus; mean age 2.01 (SEM 0.03) years; mean BW 3.25
(SEM 0.31) kg) were utilised in a cross-over design consisting of four $21 \mathrm{~d}$ periods. Each period included an adaptation phase (days 0-16), followed by a faecal and urine collection phase (days 17-21). Cats were housed individually in stainless-steel cages $(0.61 \mathrm{~m} \times 0.61 \mathrm{~m} \times 0.61 \mathrm{~m})$ at the University of Illinois (Urbana, IL, USA). All animal procedures were approved by the University of Illinois Institutional Animal Care and Use Committee before animal experimentation.

\section{Diets}

Cats were randomly allocated to one of the four dietary treatments at the beginning of the experiment: (1) beef-based raw meat (BE) diet; (2) bison-based raw meat (BI) diet; (3) elkbased raw meat (E) diet; or (4) horse meat-based raw meat $(\mathrm{H})$ diet. All diets were formulated to meet or exceed the nutrient requirements of domestic cats ${ }^{(6)}$. Diets were stored frozen $\left(-20^{\circ} \mathrm{C}\right)$ until $1-3 \mathrm{~d}$ before feeding, when it was thawed at $4^{\circ} \mathrm{C}$. Cats were fed to maintain BW, and food offered and refused were measured daily. Water was provided ad libitum.

\section{Sample collection}

Diet subsamples were collected and stored at $-20^{\circ} \mathrm{C}$. Subsamples were composited for each diet and lyophilised

Abbreviations: BE, beef-based raw meat; BI, bison-based raw meat; BW, body weight; E, elk-based raw meat; H, horse meat-based raw meat. 
in a Dura-Dry MP microprocessor-controlled freeze dryer (FTS Systems, Inc., Stone Ridge, NY, USA). To ensure complete collection and to prevent urinary $\mathrm{N}$ loss, urine was collected and stored according to $\mathrm{Kerr}^{(7)}$. Total faecal output for each period was collected, composited and dried at $55^{\circ} \mathrm{C}$. Diet and faecal samples were ground through a $2 \mathrm{~mm}$ screen in a Wiley Mill (Thomas Scientific, Swedesboro, NJ, USA).

\section{Chemical analyses}

Diets, faeces and urine were analysed for $\mathrm{N}$ according to the Association of Official Analytical Chemists ${ }^{(9)}$ using a Leco Nitrogen/Protein Determinator (model FP-2000; Leco Corporation, St Joseph, MI, USA), and gross energy was determined by a bomb calorimeter (Model 1261; Parr Instrument Company, Moline, IL, USA). Diet and faeces were analysed for DM and organic matter according to the Association of Official Analytical Chemists ${ }^{(9)}$. Diets were analysed for fat concentration by acid hydrolysis according to the American Association of Cereal Chemists ${ }^{(10)}$ followed by diethyl ether extraction according to Budde ${ }^{(11)}$, and for total dietary fibre according to Prosky et $a l^{(12)}$.

\section{Calculations}

The values were calculated using the following equations:

Apparent total tract nutrient digestibility $(\%)=$

(nutrient intake - faecal nutrient output)/nutrient

intake $\times 100$; Total $\mathrm{N}$ output $=$ faecal $\mathrm{N}$ output + urinary $\mathrm{N}$

output; Absorbed $\mathrm{N}=\mathrm{N}$ intake - faecal $\mathrm{N}$ output;

Retained $\mathrm{N}=\mathrm{N}$ intake - total $\mathrm{N}$ output.

\section{Statistical analysis}

All data were analysed using the Mixed Models procedure of Statistical Analysis Systems statistical software package version 9.2 (SAS Institute, Cary, NC, USA). The fixed effect of dietary treatment was tested. Cat and period were considered as random effects. Least square means were separated using least significant difference with standard errors of the mean Tukey's adjustment. $P<0.05$ was considered statistically significant and $P<0 \cdot 10$ was considered to be a trend. Reported pooled standard errors of the mean were determined according to the Mixed Models procedure of SAS.

\section{Results}

Dietary ingredient and chemical composition are listed in Table 1. Dietary DM concentrations were similar in the BI and $\mathrm{H}$ diets $(35-36 \%)$, and similar in the $\mathrm{BE}$ and $\mathrm{E}$ diets (29\%). Organic matter concentrations were similar among diets (93-95\%). Crude protein and total dietary fibre concentrations were greatest in the $\mathrm{E}$ diet and least in the $\mathrm{BI}$ diet.
Table 1. Chemical and ingredient composition of beef- (BE), bison$(\mathrm{BI})$, elk- $(\mathrm{E})$ and horse $(\mathrm{H})$ meat-based raw meat diets fed to domestic cats $^{*}$

\begin{tabular}{lrrrr}
\hline Items & BE & BI & E & H \\
\hline DM (\%) & $28 \cdot 7$ & 36.0 & 28.7 & 34.6 \\
Organic matter (\% of DM) & 93.8 & 95.1 & 93.2 & 94.9 \\
Crude protein (\% of DM) & 65.9 & 48.7 & 78.8 & 59.6 \\
Acid-hydrolysed fat (\% of DM) & 19.3 & 38.0 & 5.4 & 26.1 \\
Total dietary fibre (\% of DM) & 7.0 & 6.7 & 9.2 & $7 \cdot 1$ \\
Gross energy (kJ/g DM) & $25 \cdot 1$ & 28.5 & 22.6 & 25.9 \\
\hline
\end{tabular}

* Ingredient composition for all diets: raw meat source BE, beef trimmings (Central Nebraska Packing, Inc., North Platte, NE, USA); BI, bison trimmings (Natural Prairie Gold, Inc., Omaha, NE, USA); E, muscle meat (Henry Doorly Zoo, Omaha, NE, USA); $\mathrm{H}$, horse trimmings (Central Nebraska Packing, Inc.), meat complete vitamin and mineral premix (Central Nebraska Packing, Inc.) and Solka Floc.

Acid-hydrolysed fat concentrations and gross energy values were the inverse, with the BI diet having the greatest and the $\mathrm{E}$ diet having the smallest fat and gross energy contents.

BW was not affected by dietary treatment. Food intake ( $g$ $\mathrm{DM} / \mathrm{d})$ was higher $(P<0.05)$ in cats fed the BE, BI and $\mathrm{E}$ diets compared with cats fed the $\mathrm{H}$ diet (Table 2). Dietary moisture intake $(\mathrm{ml} / \mathrm{d})$ was highest $(P<0.05)$ in cats fed the $\mathrm{BE}$ and $\mathrm{E}$ diets, and higher $(P<0.05)$ in cats fed the $\mathrm{BI}$ diet compared with those fed the $\mathrm{H}$ diet. $\mathrm{N}$ intake $(\mathrm{g} / \mathrm{d})$ was highest $(P<0.05)$ in cats fed the E diet, and higher $(P<0.05)$ in cats fed the BE diet compared with cats fed the BI and $\mathrm{H}$ diets.

Apparent total tract DM digestibility was higher $(P<0 \cdot 05)$ in cats fed the BI diet and tended to be higher $(P<0 \cdot 10)$ in cats fed the $\mathrm{H}$ diet compared with those fed the $\mathrm{BE}$ and $\mathrm{E}$ diets. Faecal output $(\mathrm{g}$ DM/d) was higher $(P<0.05)$ in cats fed the $\mathrm{E}$ diet compared with those fed the $\mathrm{BI}$ and $\mathrm{H}$ diets, and higher $(P<0.05)$ in cats fed the BE diet compared with those fed the $\mathrm{H}$ diet. For cats fed the $\mathrm{E}$ diet (i.e. the highest $\mathrm{N}$ content $)$, faecal $\mathrm{N}(\mathrm{g} / \mathrm{d})$ was higher $(P<0.05)$ compared with cats fed the $\mathrm{H}$ and $\mathrm{BE}$ diets, and tended to be higher $(P<0 \cdot 10)$ compared with cats fed the BI diet. Faecal N $(\mathrm{g} / \mathrm{d})$ also tended to be higher $(P<0 \cdot 10)$ in cats fed the $\mathrm{BE}$ diet compared with those fed the $\mathrm{H}$ diet.

Urine volume $(\mathrm{ml} / \mathrm{d})$ was highest $(P<0.05)$ in cats fed the $\mathrm{E}$ diet, and higher $(P<0.05)$ in cats fed the BE diet compared with those fed the $\mathrm{BI}$ and $\mathrm{H}$ diets. The ratio of urinary $\mathrm{N}$ :faecal $\mathrm{N}$ was not affected by diet. For cats fed the $\mathrm{E}$ diet, urinary $\mathrm{N}$ $(\mathrm{g} / \mathrm{d})$ and total $\mathrm{N}$ excretion $(\mathrm{g} / \mathrm{d})$ were higher $(P<0.05)$ compared with those fed the $\mathrm{BI}$ and $\mathrm{H}$ diets, and tended to be higher $(P<0 \cdot 10)$ compared with cats fed the BE diet. Urinary $\mathrm{N}(\mathrm{g} / \mathrm{d})$ and total $\mathrm{N}$ excretion $(\mathrm{g} / \mathrm{d})$ were also higher $(P<0 \cdot 10)$ in cats fed the BE diet compared with those fed the $\mathrm{H}$ diet. Additionally, faecal and urinary $\mathrm{N}$ as percentages of $\mathrm{N}$ intake did not differ due to dietary treatment. Absorbed $\mathrm{N}$ was highest $(P<0.05)$ in cats fed the E diet, and higher $(P<0.05)$ in cats fed the $\mathrm{BE}$ diet compared with those fed the $\mathrm{BI}$ and $\mathrm{H}$ diets. Retained $\mathrm{N}$ was not affected by diets.

\section{Discussion}

Dietary composition was highly variable. The protein source for the $\mathrm{BE}, \mathrm{BI}$ and $\mathrm{H}$ diets were trimmings, while the $\mathrm{E}$ diet 
Table 2. Intake, digestibility, faecal and urinary outputs, and nitrogen metabolism in domestic cats fed beef $(\mathrm{BE})$, bison $(\mathrm{BI})$, elk $(\mathrm{E})$ and horse $(\mathrm{H})$ meat-based raw meat diets

(Mean values with their standard errors)

\begin{tabular}{|c|c|c|c|c|c|}
\hline Items & $B E$ & $\mathrm{BI}$ & $E$ & $\mathrm{H}$ & SEM \\
\hline \multicolumn{6}{|l|}{ Intake } \\
\hline $\mathrm{DM}(\mathrm{g} / \mathrm{d})$ & $45 \cdot 0^{\mathrm{b}}$ & $49 \cdot 5^{\mathrm{b}}$ & $49.5^{\mathrm{b}}$ & $38.2^{\mathrm{a}}$ & $2 \cdot 28$ \\
\hline Dietary moisture $(\mathrm{ml} / \mathrm{d})$ & $111 \cdot 8^{\mathrm{C}}$ & $88 \cdot 1^{\mathrm{b}}$ & $122 \cdot 8^{\mathrm{c}}$ & $72 \cdot 1^{\mathrm{a}}$ & 5.01 \\
\hline$N(g / d)$ & $4 \cdot 7^{\mathrm{b}}$ & $3.9^{\mathrm{a}}$ & $6 \cdot 2^{\mathrm{c}}$ & $3 \cdot 6^{\mathrm{a}}$ & 0.22 \\
\hline \multicolumn{6}{|l|}{ Digestibility } \\
\hline DM (\%) & $84 \cdot 1^{\mathrm{a}, \mathrm{x}}$ & $88 \cdot 1^{\mathrm{b}}$ & $84 \cdot 3^{a, x}$ & $87 \cdot 1^{a, b, y}$ & $1 \cdot 15$ \\
\hline $\mathrm{N}(\%)$ & $96 \cdot 6$ & $96 \cdot 8$ & $97 \cdot 3$ & $96 \cdot 8$ & 0.29 \\
\hline \multicolumn{6}{|l|}{ Faecal output } \\
\hline DM (g/d) & $7 \cdot 0^{b, c}$ & $6 \cdot 0^{a, b}$ & $7 \cdot 7^{\mathrm{c}}$ & $4 \cdot 9^{\mathrm{a}}$ & 0.52 \\
\hline$N(g / d)$ & $0.157^{a, y}$ & $0.123^{a, b, x, y}$ & $0 \cdot 165^{\mathrm{b}, \mathrm{z}}$ & $0.116^{a, x}$ & 0.0130 \\
\hline \multicolumn{6}{|l|}{ Urinary output } \\
\hline Volume $(\mathrm{ml} / \mathrm{d})$ & $78 \cdot 0^{\mathrm{b}}$ & $54.9^{\mathrm{a}}$ & $96 \cdot 5^{\mathrm{c}}$ & $47 \cdot 5^{\mathrm{a}}$ & $4 \cdot 23$ \\
\hline$N(g / d)$ & $3 \cdot 9^{b, c, x}$ & $3 \cdot 4^{\mathrm{a}, \mathrm{b}}$ & $4 \cdot 9^{c, y}$ & $2 \cdot 7^{a}$ & 0.31 \\
\hline Total N output & $4 \cdot 0^{\mathrm{b}, \mathrm{c}, \mathrm{x}}$ & $3 \cdot 5^{\mathrm{a}, \mathrm{b}}$ & $5 \cdot 0^{c, y}$ & $2 \cdot 8^{\mathrm{a}}$ & 0.32 \\
\hline Absorbed N (g/d) & $4 \cdot 6^{\mathrm{b}}$ & $3 \cdot 7^{\mathrm{a}}$ & $6 \cdot 1^{\mathrm{c}}$ & $3 \cdot 5^{\mathrm{a}}$ & 0.23 \\
\hline Retained N (g/d) & 0.68 & 0.36 & $1 \cdot 21$ & 0.81 & 0.342 \\
\hline
\end{tabular}

was composed of trimmed muscle meat. Trimmings are often high in fat and highly variable. The E meat source was overtrimmed, and the percentage fat (5.4\%) was lower than our estimates and recommendations for domestic cats ${ }^{(8)}$; however, because of the short time span for the study, no negative effects were observed. Dietary composition differences were reflected in dietary moisture $(\mathrm{ml} / \mathrm{d})$ and $\mathrm{N}(\mathrm{g} / \mathrm{d})$ intakes for the BE, BI and $\mathrm{E}$ diets. Although the $\mathrm{H}$ diets had higher $\mathrm{N}$ and moisture levels than the BI diet, the DM intake was decreased in cats fed the $\mathrm{H}$ diet, so intake of these variables was lower in cats fed the $\mathrm{H}$ diet.

Differences in DM digestibility were not attributable to differences in $\mathrm{N}$ digestibility but may reflect the digestibility of other dietary macronutrients (i.e. fat, carbohydrate, etc.). Apparent total tract DM and $\mathrm{N}$ digestibilities reported in the literature for raw meat diets were similar to those reported in the present study (84.1-88.1\% of DM; $96 \cdot 6-97 \cdot 3 \%$ of $\mathrm{N})$ and ranged from 83 to $95 \%$ of $\mathrm{DM}$ and from 88 to $96 \%$ of $\mathrm{N}^{(4-7)}$. Lower dietary percentage DM and higher DM digestibilities of the $\mathrm{BI}$ and $\mathrm{H}$ diets resulted in lower faecal DM output $(\mathrm{g} / \mathrm{d})$ measured. Because $\mathrm{N}$ intake $(\mathrm{g} / \mathrm{d})$ varied across treatments, but digestibility was similar, faecal $\mathrm{N}$ was reflective of $\mathrm{N}$ intakes.

Differences in urine volume $(\mathrm{ml} / \mathrm{d})$ and urinary $\mathrm{N}$ output $(\mathrm{g} / \mathrm{d})$ reflect differences in dietary moisture and $\mathrm{N}$ intakes, with higher intakes having higher urine volume and $\mathrm{N}$ excreted. The average ratio of urinary N:faecal $\mathrm{N}$ was $27 \cdot 1$ (SEM 6.8), indicating that the majority of $\mathrm{N}$ was excreted in the urine, and the profile of $\mathrm{N}$ output was not altered, with $3 \cdot 1$ (SEM $0 \cdot 7)$ and $81 \cdot 0(\operatorname{sem} 17 \cdot 7) \%$ of $\mathrm{N}$ intake being excreted in the faeces and urine, respectively.

Although retained $\mathrm{N}$ was positive, cats maintained BW. This phenomenon is common in domestic cat $\mathrm{N}$ balance studies that examine high-protein diets and is due to $\mathrm{N}$ that is unaccounted for rather than truly positive $\mathrm{N}$ balance. Values reported in the present study are similar to those in the literature for extruded ${ }^{(13,14)}$ and purified diets ${ }^{(15)}$.

\section{Conclusion}

Due to differences in the meat sources, dietary protein and fat concentrations were highly variable. Digestibility of DM and N was high, and cats maintained BW and $\mathrm{N}$ balance for all treatments. Differences in intake, absorption, and faecal and urinary excretion of $\mathrm{N}$ were due to differences in dietary $\mathrm{CP}$ levels. Urinary $\mathrm{N}$ accounted for a majority of total $\mathrm{N}$ excretion, and differences in total $\mathrm{N}$ excretion reflect differences observed in urinary $\mathrm{N}$. $\mathrm{N}$ retention was similar to values reported in the literature for domestic cats. Despite having different chemical compositions, beef, bison, elk and horse meat appear to be suitable protein sources for raw meat diets. However, further research on these protein sources for use in raw meat-based diets for domestic cats is necessary, including evaluation of long-term effects.

\section{Acknowledgements}

The present study was supported by the USDA National Institute of Food and Agriculture, Hatch Project no. ILLU-538.396. K. R. K., C. L. M. and K. S. S. contributed to the conception and design of the study. K. R. K. and A. N. B. performed the animal trial and laboratory analyses. K. R. K. performed the statistical analyses, interpreted the data and drafted the manuscript. All authors contributed to the revision of the manuscript and approved the final version. There is no conflict of interest for any of the authors.

\section{References}

1. Freeman LM \& Michel KM (2001) Evaluation of raw food diets for dogs. J Am Vet Med Assoc 218, 705-709. 
2. Center For Veterinary Medicine, FDA (2004) Guidance for industry \#122. Manufacture and labeling of raw meat foods for companion and captive noncompanion carnivores and omnivores. http://www.fda.gov/downloads/AnimalVeterinary/GuidanceComplianceEnforcement/GuidanceforIndustry/ ucm052662.pdf (accessed 8 October 2010).

3. Hill RC (1998) The nutritional requirements of exercising dogs. J Nutr 128, 2686S-2690S.

4. Morris JG, Trudell J \& Pencovic T (1977) Carbohydrate digestion by the domestic cat (Felis catus). Br J Nutr 37, 365-373.

5. Kendall PT, Holme DW \& Smith PM (1982) Comparative evaluation of net digestive and absorptive efficiency in dogs and cats fed a variety of contrasting diet types. J Small Anim Pract 9, 577-587.

6. NRC (2006) Requirements of Dogs and Cats. Washington, DC: The National Academies Press.

7. Kerr KR (2010) Nitrogen metabolism, macronutrient digestibility, and fecal fermentative end-products in domestic cats fed extruded, raw beef-based and cooked beef-based diets. MS Thesis, University of Illinois.

8. Vester BM, Beloshapka AN, Middlebos IS, et al. (2009) Evaluation of nutrient digestibility and fecal characteristics of exotic felids fed horse- or beef-based diets: use of the domestic cat as a model for exotic felids. Zoo Biol 29, 432-448.

9. AOAC (2006) Official Methods of Analysis, 17th ed. Arlington, VA: Association of Official Analytical Chemists.

10. AACC (1983) Approved Methods, 8th ed. St Paul, MN: American Association of Cereal Chemists.

11. Budde EF (1952) The determination of fat in baked biscuit type of dog foods. J Assoc Off Agric Chem 35, 799-805.

12. Prosky L, Asp NG, Furda I, et al. (1984) Determination of total dietary fiber in foods and products: collaborative study. I Assoc Off Anal Chem 67, 1044-1052.

13. Funaba MT, Tanaka M, Kaneko T, et al. (2001) Fish meal vs. corn gluten meal as a protein source for dry cat food. $J$ Vet Med Sci 63, 1355-1357.

14. Funaba MC, Matsumoto K, Matsuki K, et al. (2002) Comparison of corn gluten meal and meat meal as a protein source in dry foods formulated for cats. Am J Vet Res 63, 1247-1251.

15. Green AS, Ramsey JJ, Vilaverde C, et al. (2008) Cats are able to adapt protein oxidation to protein intake provided their requirement for dietary protein is met. $J$ Nutr $\mathbf{1 3 8}$, 1053-1060. 